\title{
The Beginnings of Wessex
}

TT has long been evident that we cannot accept without question 1 the story of the conquest of Wessex told by the "Old-English Chronicle.' It is enough to jnstify the doubts to reflect that the - Chronicle ' gives the dates of events that happened a century before the first conversion of an English king to Christianity, the earliest date at which it would have been possible to commit the annals to writing. Of the use of runes for keeping annals there can be no question. $^{1}$ It is therefore evident that these annals must rest upon a basis of song or tradition or be figments of later times. - The latter is the view that Sir Henry Howorth maintains in the October number of this Revier. According to him they are a concoction of the time of Edwarl the Elder, which he holds to be the date of the composition of the 'Chronicle.' The procedure of this concoctor, according to Sir Henry Howorth, was singular to a degree. Not being satisfied with taking a list of Welsh names, possibly 'some series of Welsh princely names,' and passing them off as the ancestors of his king, he pressed into his service the very latest novelty in the shape of a man's name-to wit, the Scandinavian Stiffr, which he conferred upon an unnecessary nephew

1 Palgrave, Englich Comnonwoalth, i. 891, suggested the use of runes for this purpose, and they are referred to by Freeman, Norman Conquest, i. 10. Bcherer, Geschichte der doutschen Jiteratur, p. 29, has traly remarked that they were never ueed in this way.

- The name Stuf, upon which this assertion restr, has been olsimed as Soandinavian by E. Jessen, Undersingelser tzl nordisk Historic, p. 55, who endenvoured to prove from it that the English Jutes were Scrndinavians. It is exceedingly donbtfol whether the Norse stiff wins in use as a personal name enrly enough to support Bir Henry Howorth's assertion. It n'as reslly a nicknome, mesning 'stump.' In the sagas I have been able to trace only two men bearing this name, both mach later in date than the Chronicle. One is the Greenlander Stufr, a retainer of St. Olaf of Norway, and the otber is the blind scald of Harald Harirada. who accompanied him to Stamford Bridge. The excessive rarity of the name may le gauged by the tule told in the saga of this king. When Stuifr informed the king uf his name, the laiter remarked, ' You have an improbable ' (únafuliugr, literally ' un-name-like') 'nnme' (F'latewjar.bák, iii. 880). Phonologically there is nothing to prove that stuf is not a native English form, whether it corresponds to the Norse Sifhfr, which is assamed to stend for Siumf, or whether it is the English cognate of the Greek orúror, which is recorded in the derivatives stybb, stofn, and styfic. Nearly every Germanic language affords instances of personal names that occur only once or twice, and this is more especially true of hypocoristic forms, a category to which Stuf, being a single-stem name, seems to belong. I do not think that the name Stuf can be brended as bogus by reason of its rarity, and I can see no valid reason for holding that it is borrowed trom the Norse. 
of the bogus founder of Wessex. All this is so astonishing that it is worth while to exsmine Bir Henry Howorth's statements.

After setting forth several seeming inconsistencies in the norrative, upon which he lays great stress, but which are non-existent or unimportant, 'he brings forward the familiar suggestion that some of the names of the actors are evolved from place names. It is easy to make these suggestions, especially when one is not fettered by considerations of the laws of Old-English philology, and we have had many such suggestions. ${ }^{4}$ It is not explained why, given the fact that Cerdices-leay, dic., is derived from a man's name Cerdic, this name should be selected out of the thousands of personal names embodied in local names with which the concoctor must have been familiar and converted into the founder of the kingdom. If it had been a nume familiar in Germanic song, we might understand the choice, but it is a rare and difficult name. Some of the alleged inventions are quite unnecessary for the history. We hear nothing more of Port, Bieda, and Mægla, or of their descendents. The reference to the death of a very noble young Briton during the fight following their landing has the sppearance of being derived from a lay or tradition.

Of the nine names cited by Sir Henry Howorth and denounced as being either Welsh or non-Teutonic, there are only two that have any claim to belong to these categories. One of these is Cerdic,

I I nnnot see what is meant by seying that the deseription of Cerdic and Oynrio es 'two caldormen involves an anachronism.' Ealdorman is the natural OldEnglich word for ohief, and it is applied to Romans, Britons, and men of other reces. In the Chronicle we read of the sleying of 'twelve Welsh ealdormen' in 463, and of 'two ealdormen' in 568. Thore is no serious difficulty about the pasesege in 684, where Stuf and Wihtgar are called nefan of Cerdio and Cynric, who are stated to be tather and son. The word rofa in Old English does not mean exclusively 'nophew,' but may mean ' grandeon ' or even 'stopson.' It is historically the seme word as the Latin nepos, Greek arrwebr, dc., an Indo-Germanic word that has no olearly defined meaning beyoud that of 'Kingman ' or 'descendsnt.' Bir Henry Howorth objects that Port, Becte, and Mmgle are made to slay ' not the Wales, but a young British man.' This seoms to have no point unless it is intended to convey that Briton is not synonymous with Wealh, or that one man only was slain on this cocasion. The former aan essily be disproved by the Chronicle itself or by Bedes while the latter is exoluded by the faot that the Chronicle ang 'a very noble young Briton,' not eimply ' a young British man.'

- Thus Profesgor Earle (Twoo of the Saxon Chronicles Parallel, p. ix) suggested that Shoreham, Lancing, and Chichester (Cissan-ceasher) were probably responsible tor the names of Elle's mons Cymen, Whencing, and Oiasa. The former town is held to stand for the impossible Cymeneshoreham, while there is nothing to connect the pre-English name of Chichester with any neme like Ciase. The initiv wol in Old English names was still pronounced at the time of the Norman Conquest, and we may be sare, therefore, that the Lancinges of Domesdey had no initial w. Whencingas would heve produced something like 'Linohing.' The neme-stem from which Whencing is derived appesirs in Domesday in the form Walanc (s O.E. Whanc) in Walancastau (L. 869). Bimilarly Domesday represents O. E. Wr. by Wur- or Wer-. The essertion that the Hrof of Hrofes-caster is from Durobrevis is one of the eariosities of that strange book, the Romans of Britain, by H. C. Coote.

voL. XIV.-NO. LIII. 
which he roundly states to be 'merely the Welsh Ceredig or Caradoc.' This was anid by Sir Francis Palgrave," but the Welsh names are distinct, and there can be no talk of the latter appearing as Cerdic. It is questionable whether Cerrlic can represent Cerenig, for that name, originally Comticus, ${ }^{8}$ appears much later as Ceretic,' and there is no reason for the disappearance in early West-8axon of the medial and accented vowel, or for the change of $t$ to $d$. The reason for saying that Cerdic is Welsh is its occurrence in Beda as the name of a Welsh king. ${ }^{8}$ Beda's form puzzles the Welsh

- English Commonwosalth, 1. 899, note.

- Rhys, Celtic Britais, p. 367, oiting a letter of Bt. Patrick in Haddan and Btabbs, Councils, li. pp. B14-819. So 8t. Brienc's Life of Cardigan (Ceredigiaten) 'gens Corritiaiana ;' AA. SS., $1 \mathrm{Mali}, 1.92$.

I In the Book of Bt. Chad (Rhys and Evans, Liber Landaverio, pp. 199, 220, 247, 279) it is mritten Ceretic between 874 and 902.

- Historia Ecclesiastica, iv. 28; probably the Certic, king of Elmet, of the Historia Brittonum, ed. Mommsen, p. 206. The spelling here is probsbly besed apon nn English manusaript, for the Creneslogies in whioh it occurs repeat English inflexional forms in the Latin, they copy the $D$ as $D$, and show generally that they are derived from an English original. Zimmer, Nonnius Vindicatus, p. 78, holds that tbey were the work of a northern Briton. The alleged interpreter of Hengist and Vortigern Is called Ceretic in the best MBS. of the Historia, thongh others exhibit the forms Cerdic, Cedic (ed. Mommaen, p. 177). The peseage t tecit Henogistag convivium Gaorthigirno et militibus suis et interpreti sao, qui rocetar Ceretic,' has been read by Mallenhoff (Beotoulf, Berlin, 1889, p. 62) to mean that Cerdio signifles 'interpreter,' and he relers to Irish etarcert, 'interpretatio;' olercerta, ' interpretatur,' \&o, in Zeuss-Ebel, Grammatica Celtica, p. 874. But Prof. Rhye thinks it probable that this cert. would appear In Welah with a $p$ instead of $c$. Moreover the omisaion of the char = inter would seriously change the meaning. The form of Cordic in English is irregular. If trom Cordic, it ought to appese as Ceordic. The form Ceardic, which cocurs occasionally in the genealogg in the Parker MB., and in the Bomewhat earlier text In 8weet's Oldest English Texts, p. 179, would normally represent an older Oardic, but in Alfred's time there are Instances of the confusion of ear and sor plun a conenent. Ct. Cosijn, Altwostsichsische Grammatik, 1. 8 18. An undoubted Cordic, Coardic, Cardic was a praefcctus (misprinted presbyter) of king Cynewull of Wescex, and atteste between 750 and 774 (Cart. Sax. i. 286, 284, 814). The terte are derived trom later chartularies, and they may all represent an original Cardic, for thirteanth and fourteenth century scribes copy as as ea or a simply. The Ceardices-beorg of the twalfth century Codex Wintoniensis (Cart Sax. if. 241) at Hurstbourne, Hante, mag also represent a Cerdic in the seme way. An unknown Bishop Oerdic subsaribes a oharter of 981 (Cod. Diplom. iil. 184). 'The stem of the name oocurs also as a name in 949, Cardan hlaw, 'Carda's tumulus,' at Welford, Berks (Cart. Bax. ill. 29, an original charter), which is copied into the Abingdon Chartalary from a charter of 856 as Oerdan or Cardan heaw, for hlaw (Cart. Sax. iii. 147). There was also a Cardas otigal at Poiwick, co. Worcester (ibid. 688, trom a pre-Norman text). OL also Cardington, $\infty$. Balop, Cardinture, in Domeday, 1. 255. There are also Cond forms in Condontome, Domesday, 1. 180 b, co. Middlesex, for Cerdan-tun and Cerdss-ling (9 Charlinob), $\infty$. Bomerset (ibid. i. 93, col. 2), and Cerdas-lai, Chearsley, co. Buaks (ibid. i. 100), a forth that cannot be reconciled with Dr. Guest's atrange identification of this vllige whth the Cerdices-leag of the Chronicle. Domesday (i. 266 b) also recurds a Oheshiro Car. dirgham. The use of the Engligh hypocoristio suffix a in these names alearly proves that the stem Cord or Card had been adopted into English, whstever Its ultimato origin may have been. It is possible that the stem Card is repreanted by Cadd(a) and $C e r d$ by $\operatorname{Ced} d(a)$, which would be regular hypocoristic formations. The posdblity. of borrowing from the Britons betore the English conquest annot be enaluded from 
philologist quite as much as it does the English, for it stands absolutely alone. A very great German scholar has suggested that Cerdic the West-Saron may have derived his name from connexion with the Britons of Aremorica.' The next name is Port, which we are told was 'manufactured out of the Latin Portus.' This may be so. But there is evidence that Port did exist as an English personal name. ${ }^{10}$ Müllenhoff held that Port's name was evidence of relations with the Romans, which he referred to Gaul, the coasts of which the Baxons had been harrying for more than a century before Port was born. We are next told that 'Cynric (or Kenrick) is also a Welsh name.' There is, it is true, a Welsh name Cynuric, ${ }^{11}$ from which Kenrick may descend, ${ }^{12}$ but Professor Rhys tells me that this seems to be an adaptation of an English neme. It could not in any case appear as Cynric in the ninth or tenth century. The latter, so far from being a Welsh name, is an undoubted English one. ${ }^{13}$ We then read that 'Elesa and Esla are apparently forms of one name, and that neither of them is Teutonic. The only ground for the latter assertion is that there is a Welsh Heli. Now Elesa and Fsla are distinct names and are

consideration. The Norsemen at a later time borrowed several Celtic names, such as Kormakr, Nial, and the Nialsaga shows as an Icelender bearing the Irish name of Nial as early as the tenth century. Yet his sons bear Norse names.

- Karl Mällenbof, Beowulf, Berlin, 1889, p. 62. But, as will be been the ettlement in Aremorica does not seem to hive taken place early enough for this

10 Thas there is a Portes raadu at Stoneham, Honts (Codex Diplum. iv. 95), and a Portas-bricg in the same pisoe (ibid. iv. 9ti); Portesham, co. Dorset, Portes-hamme (ibid. iv. 30); Portishead, co. Somerset; I'ortes-Lade, co. Sussex (Porkes-lage [?]) (Domesday Book, i. 26 b, ool. 2); Portes.ig (Cod. Diplon. iv. 191). There is a Portington in $\infty$. York, whose Domesday form (Portilon, i. $\mathbf{3 0 4}$ b) may represent Portingtun or Portan-tun. The Portan-mere in Worcestershire (Cart. Sax. iii. b3y) contains the hypocoristic suffix $\cdot a$, and the same neme seems to occur in Portan-bcorg, co. Wilts (Cod. Diplom. iv. 1, printed Wortan in Cart. Sax. iii. 240). It is not impossible thet Port and Porta may be native English, for the Mercian royel family shows us several Germanic names beginning with $p$, which seem to have changed their initial by some unknown hypocoristic law. There are traces of the related pertonal names Purta and Pyrta, and a Germanio port seams to be recorded in the O.-E. verbs portiam, pyrtan, 'to beat.' A continental Porto, a monk of the Poiterin Cherroux (Vienne), ocara in the ninth centary at Reichensa (Lib. Confrat. A ujiensis, ed. Piper, col. B48, 32). Bat it is not clear whether this corresponds to O.E. Porta or to Bsirda (by the High-German sound-change).

"Kymoric, Rhys and Evans, Rad Book of Hergest, pp. 260, 311, 324, 368.

12 The confusion with the English neme may be seen in the Calentar of I'atent Roll, Edward I, where a Cynwric, son of Llywarch, appears in 1294 es Kensiureh, aon of Louhargh (p. 121), and in 1292 es Konrick, son of Thlewargas (ibid. p. 621). An inatructive example of the adoption of Old-English names by the Welsh may be seen in the Grifin sp Herevoard of this Calendar, p. 243. The Liber Jamiatcnsis reveals numerous instances of English personal names in Welkh districts in the eleventh and trelith oentaries.

13 Tho more agual and later form is Cyme-tic, but Cynric is regular. Ct. Sievers, Anglia, xlii. 13, for the syncope. It seems to occur in the corresponding Old Hifb Cterman Chun(i)rih (Forstemann, ditdeutsciles Namerbuch, i. 315). 
English and Germanic." Sir Henry then states that "Giwis or Gewisar again is no Teutonic name,' apparently becruse the Welsh called the West-Saxons by this name. But there is clear proof that it was the native denomination of the latter, and that it is not Welsh.". Next we are told that ('mlic's-ura 'is compounded of the Latin ora and the name Cerdic,' and that 'it seems impossible as a Teutonic gloss. The word ora is a genuine Old-English one, which shows by its gender, declension, and form that it is not the Latin ora, but is a cognate. It is then stated that 'Bieda and Mægla are very un-Teutonic in look, and Mægla seoms to be certainly a Welah gloss.' Buth these names are English, the former being the spelling of the great Northumbrian historian's name in the Parker MS. of the 'Chronicle,' ${ }^{16}$ while the latter is a regular hypocoristic form of a full-name in Mèg-, a well authen-

"The former occuirs as Files and Eliso in the ninth centary in Germany (Liber Confralcrititatis Augiensis, ed. Piper, 41, 18; 408, 12; 158, 28). See turther Förte. mann, i. 69. It is gpolt Elsa in the Old-English Widsith, line 117. I have failed to find an English bearer of thin name, but, $s$ it is genuine Germanio neme, this is an argument that the West-Saxon pedigree is not a lorgery of the tenth century. The name of the mont Elsan or Ilsan of the Niebelingen Lied is connected. While Elesa represente a Germanic Aliso(n), Ésln is descended from Ansila(n). Th18, whioh is a hypocoristic form of a name in Ans., O.E. Üs., was the name of an ancestor (Ansila) of the Gothio kings, ecoording to Jordenes, and it is met with elsewhere on the continent (Forstemann, p. 103). Like K'ksa, it is a proot of the antiquity of the Wert-Saron genealozy, for in Old English this form of the name was superseded by the new formation Oala.

is That the (iinoys of the Annales Canubrine is an edaptation of the English travis is proved by the form Iwojs of the 'Brat $y$ Tywyssogion' (Red Book of Hergest, ed. Rhys and Evann, p. 260). for 0 . E. gi or ge might be represented by $i$, but a Woluh gi could not possibly be. Wo have not only the express statements of Beds ('gens Oooi. dentalium Rexonum, qui anti, puitus Geuissae vosabantur.' iii. 7 ; ' episcopus Geuissorum, id est Occidentslium Sasonum' iv. 15. \&0.), but the fact that the kings of Wossox desoribed themselves as 'lings of the Qewixse,' a title that was revived by King Bdgar in the tenth century. Sunith suggented that the name might be connected with the Disi- of the Visigoths, a word that does not seem to mean ' west,' but to be the Germanic representative of Indo.Cermanic wesu-s, ' good' (Skt. rdau-J. Gaulinh veau-). The Viripotha, it may be noted, are celled simply Hiani, llisi by Trebellius Poltio, Cleudian, and Apollinaris Sidonius. Soe Professor Stroltberg, Indogermaniache Foracliungen, iv. 302. They aro, no doubt, the Visi of the Notitia Dignitatum Or. v. 61 (ed. on their Gothic nationality. Mullenhoff (Beotulf, p. 63) has conneoted the Weat-Baxon name with the Oothio ga-wies, 'junction,' and would thus explain it 28 'confederates.' In this case Oewois must be rogarded as an eponym. Instanoes are, however, not anknown among the Germanic peoples of the folk being known by a name derived from an anoestor, real or mythical, of their rojal house. Thus the Danes were called Skibldungar, trom Shivld, the Scyld of Beowulf, name that is applled to them, in the form Sealdingi, in the Historia de Sancto Cuthberto, od. Arnold (Simeon of Durham, i. 800, 202). The Franks imilarly aro callod Merowio. ingas (Merowings) in Beowulf. The stem Wisi cocurs in the name of the Lombard Wisigardis, the wite of Theodebert I.

IA Sab ann. 734. Similarly Biadan.lkeafod in 678. The game stam, with anothor hypocoristic suffix, occurs in Biedcan-ford in M8. B, C, and E in 671, where the Parter M8. hes Bedcan-ford. 
ticated English and Germanic name-stem. ${ }^{17}$ We have then the familiar assertion that "Wihtgar is assuredly merely condensed from the men of Wight '-that is, the Wiltticare. The genitive plural of this form is irara, but the archetype of the 'Chronicle ' used the older weak form 1 ara, ${ }^{18}$ the genitive plural of which is veurena, so that we ought to have Wihticarena-burh, not Wihtgara-burh. The change of $w$ to $g$ in such a position as is here assumed is unknown in Old English, and it never occurs in any of the numerous compounds of vare or waru. ${ }^{19}$ On the other hand, Wihtgar is a wellestablished Old-Engliah masculine name, the first stem of which has na connexion with the Iele of Wight, but is our wight, ${ }^{00}$ which in personal names probably refers to the Eaipay or genius of Germanic paganism (cf. Elf-gar). It is on record that the second member gar was in Old English a $u$-stem, ${ }^{21}$ and therefore originally formed its genitive singular in -a (gdra). Most of these stems in Old English went over to the $o$-declension, and therefore formed their genitive singular in -es. By the ninth century the number that retained their original declension could be counted on the fingers. It is therefore evident that this W'ilitgara-lumll of the 'Chronicle,' which is there said to be the burial-place of Wilktgar, can only be derived from some older written form or possibly tradition. We can see from the Parker MS. that the scribes were puzzled by this archaic genitive singular, for they convert the correct Wihtgara-byry of 544 into Willgaras-byrg under 590, under the influence of the genitive Willtgares with which alone they were acquainted." This preservation of the old genitive was first recognised by Professor Cosijn of Leyden, the distinguished author of a grammar of Old West-Baron, and it has been accepted by the supreme authority on Old English, Professor Sievers of Leipzig." It is not beyond the reach of the long arm of coincidence that a Wilitgar should have ruled in Wight.

17 German forms are given in Porstemann, i. 885.

1" Sub ann. 681.

10 The Wihtgara of the tribal hidage (Catl. Sax. i. 114) may be thought to refer to Wight. But the hidage is only lialf that of Wight as given by Berde, and the list ceems to relate to non. West-Saxon districts. Cl. Maitland, Domeaday ard Beyond, p. 307 , note. It is possibly a mistake of the copyist for Wihtgaga, since it precedes Nas gaga and Oht gaga. From its position in the list it should bo somewhere near the Chiltern..

- Ct. Much, in Paul, Braune, and Sievers, Beifrage nur (ieschichte der deutseluen Sprache und Litcratur, xvii. 30 . An early instance of the stem is the Victi-marius of - Rhenish inscription, which bas been claimed erroneously as Celtic. Cf. W. Reeb, Germarische Namen auf rheirisches Inschriften, Mains, 1895, p. 42. It has also been saggested that Wight-in Germanic names may be the unrecorded cognete of the Welsh growith, ' battle,' from an older toect.

a In the Epinal Olossary the compound ast-gar" for the later cet-gir occurs thrico (ed. Bweet, Oldest Erglish Terts, 440, 839, 922). On this very archaio form aeo Bievers, Britrilgo, ix. 273.

2 This has been already remarled by Bievers, $l$. $c$.

- Taalkundige Bijdrage, ii. 272.

is Angeladchrische Grammatik, ed. 2, 1886, ed. 8, 1898, \$ 279, note 2. 
If the Winta of the Lindsey pedigree had been connected with Hampshire, we should have been told that he had been manufactured out of Wintan-ciaster, the Latin lenta.

There are other philological proofs that the annals rest apon a written basis older than the time of Edward the Elder. The WestSaxon geneslogies retsin traces of eighth-century orthography, and Professor Napier has referred; them to an original written before 750.2) The genealogies are a separate work from the 'Chronicle,' and it may therefore be contended that the latter is really a forgery of the tenth century. But here, again, we have philological evidence that cannot be reconciled with Sir Henry Howorth's theory. The scribes of the 'Chronicle' fortunately copied carefully many of the old written forms. Hence we get, in addition to this old genitive Willtgara, such forms as Giris, the !i of which must go back to the early part of the elghth century at the latest, ${ }^{26}$ since by that date it had assumed its later form of $! \mu$. Another proof of early origin is the use of liayl in indredes-lea!l and no doubt in Cerdices-leay, Natan-leag, and Fethur-leng, in the sense of 'wood,' for by the latter part of the eighth century this word had acquired the sense of 'field.' ${ }^{27}$ We know from its continental Germanic cognates that it must once have meant 'wood,' a conclusion supported by its Latin cognate lucos, older lomkns. Unless the liaga of Andredesleaga in 508 and Cerlices-len!/a of 527 is latinised, which is unlikely, ${ }^{28}$ they must represent the dative singular, used as a nomjnative, of a "-stem. By Alfred's time the dative singular was leaye.

The theory that the early annals are partly founded upon' songs is supported by the fact that there are distinct traces of a metrical origin. It would indeed be strange if the English had no lays relating to the conquest when they had poems concerning the conquests of Goth and Lombard, their own tights with the Danes before the migration from Germany, and so much of the early history of Sweden as is preserved in Brouculf. This work, which was oommitted to writing about the year 1000 , preserves a wonderfully acourate account of a Scandinavian inroad into Holland that occurred, according to Gregory of Tours, ${ }^{30}$ between the years 512 and 528. The interval between the event and the committing of the song to writing is greater than we should have to assume in the instance

3 Hodern Langrage Noles, xii. p. 110.

t* In the Epinal Glossary, which represents a seventh-century work, the gi form is the most common, bat the later ge oocurs (Ferdinand Dieter, Ueber Sprache und Mundart dor illesten englischen Denkmiler, Güttingen, 1885, \$89).

"Thus, in a contemporary charter of $\mathrm{No5}$, cempas srmentorum, id eat hritra lesh' oceurs (Cart. Sar. i. 450).

- In the O.E. Latin charters and writings the names are very seldom latinised.

? Sweet, Englisclue Studien, ii. B10, has shown that the ammal of 173 preserves fragments of an alliterative poem in 'unarimedlico herereaf,' and In 'Alugon pa Englo stra fyr,' and that the annels of 457, 491, and 501 also soem to have a metrioal basia.

- Historia Francorum, iii. c. 8, where it is assigned to c. 816 by Arndt. 
of the 'Chronicle.' The disappearance of the songs need create no difficulty, for few of the old lays were ever written down, and few of those that were thus faroured have come down to as. We should have had no trace of the fine lay of Maldon if it had not been for the energy of Thomas Hearne. As late as the fourteenth century, the English pessants were still acquainted with the story of a hero of North Germanic 8ong of whom we would fain know more, the god or demi-god Ing," the 'Stammvater' of the Ingarevones, the great confederacy to which the ancestors of Baxon and Angle belonged in the first century of our era.

Sir Henry Howorth bases an argument against the authenticity of the early West-Saxon annals upon the fact that Beda derived information relating to Wessex from Bishop Daniel of Winchester, and that he does not mention the battles of Cerdices-ford and Cerdices-leag and knows nothing of Cordic and Cynric. This argument loses sight of the nature of Beda's work, which is almost exclusively ecclesiastical in its interests. It is no mere inference that the information supplied by Daniel was ecclesiastical only, but an express statement of BedB. ${ }^{32}$ This writer had little concern with the details of the foundation of the English kingdoms. All that he tells $\mathrm{us}$ is that Hengist and Horsa were the leaders of the first band of invaders, ut perkibentur. As he says nothing of the conquest of his own land of Northumbris, it is unressonsble to expect him to record that of distant Wessex. His 'perhibentur' in reference to Hengist and Horsa and their pedigree given by him suggests thet he had before him materials of a similar nature to those that seom to have formed the basis of the early West-Beron annals.

The non-appearance of the West-Saron genealogy in Nenning does not compel us to conclude that it is a forgery of the tenth century. The pedigrees copied into this work were derived from a compilation that was taken up to about $750,{ }^{23}$ and we have philological evidence that the West-Saxon pedigree must have been committed to writing at or before that time. We have an older copy of the Northumbrian collection of royal pedigrees that were çopied into the 'Historia Brittonum.' ${ }^{4}$ As some of the pedigrees end in

"Robert of Brunne, Chronicle, to. 85:

Bot of Inge seub I never nouht

In boke writen ne wrouht,

But lewed men thereot crie

And maynten that ilke lie.

Of. Binx, Zougniese rur gennaniechen Sage in England, in Pad, Brane, and Bievers, Boitrage, 1x. 151.

- Preafatio to Hist. Ecel.: 'Bed et Danihel, reverentissimas Oooidentelium Saxonum episoopus, qui nunc usque superest, nonnulla mihi do historis coclesiastion provincies ipsias . . . litteris mandeta declarevit.'

- Zimmer, Nennius Vindicatus. 78 sqq.; Tharnejsen, Zeitsekrift fur deuteche Philologie, Ixviii. 101.

4 Printed in 8weet's Oldest English Texts, p. 169. This wes written betore 814. 
about $680,{ }^{23}$ it is evident that the nucleus of the work goes back to that period. Beda mentions the keoping of lists of kings in Northumbria in the seventh century in words that may possibly refer to some date near 634..$^{\text {.6 }}$ The Northumbrian collection inoludes the Anglian and Jutish kings only. None of the Saron kings are inserted. If it were not for the appearance of Mercia ${ }^{37}$ in it, might assume that the kings of Wessex, Essex, and Sussex were omitted because they were pagan when it was drawn up, and were therefore like the two kings mentioned by Beda, left out of 'the catalogue of Christian kings.' These three kingdoms were still pagan in 630.

Sir Henry Howorth repests Kemble's objection to the 'Chronicle' account that Cerdic is made to die forty years after his arrival, and that Cynric, who is described as joint leader upon their arrival in Britain, reigned twenty-six years after Cerdic's death. This is branded by Sir Henry Howorth as 'outrageous,' but it cannot be said to be impossible. The 'Chronicle' speaks of King Alfred as joint leader with his brother at the age of nineteen, and the reader of sagas must recollect how frequently the horo acts as a leader at an earlier age than this. We may also think of the early age at which the sons of the duke of York are leaders in bettles during the Wars of the Roses. Cynric might well have lived to eighty-six, and thus have been twenty at the time of his arrival in Britain. Ethelberht of Kent reigned fifty-six yesrs, according to Beda, while Penda of Mercis succeeded to the throne at the age of fifty and reigned thirty years afterwards. Noreover, the genealogies say that Cerdic reigned sixteen years, and that his reign commenced six years after his arrival, which they place in 494 . Thus his death would be in 516, or 517 if we adopt the date of the landing given by the 'Chronicle.' The latter work tells us that Cerdic and Cynric began to reign in 519, and that Cerdic died in 584. Several of the texts of the genealogies insert a Crioda between Cerdic and Cynric, and this would seem to have been the reading of the archetype. ${ }^{2+}$ It is evident that there has been some confusion of Cerdic and Crioda. ${ }^{3}$ Possibly they have been wrongly identified through the similarity between the forms Cerdic (or Ceordic ?) and Creoda, and the resemblance of the eighth century $a$ to ac. It is therefore possible that the entry in the 'Chronicle ' under 519 may mean that Crioda, not Cerdic, and Cynric began to reign, and that it was Crioda, not Cerdic, who died in 534. In that case the duration of Crioda's reign would afford another reason for confusing him with Cerdic.

5) Zimmer fixes the date as 685-6 (p. 78).

- H. E. iii. co. $1,9$.

n Zimmer and Thurneysen (p. 85, note 4) regard the Mercien pedigrees as interpolated.

- Napier, L. c.

- The names are distinct, even if Cerdic be regarded as a metathesis of Credic, for Crioda appears in the Mercian pedigree und in local names. 
A further objection raised by Sir Henry Howorth is that be has alwaye been puzzled to know where the Saxons can have come from at the end of the fifth century, since ' their raids were a thing of the past in the year 500,' and he is struck by the singularity of their landing so far west as Charmouth ${ }^{40}$ in Dorset. The former is a difficulty that historians have not generally felt. We have the evidence of Apollinaris Sidonius that the Saxons were still active on the cossts of Aremorica at a time when Cerdic might have participated in their raids." I am tempted to throw out the suggestion that the settlements on the soith cosst of Britain were a result of the power of Clovis resching the eset cosst of Geul, and thus diverting the attempts of the Saxons to settle in Gaul to Britain. ${ }^{4}$ The attack upon Angers in 463 by the Saxons under Esdwøccer (Adovacrilus) ${ }^{43}$ seems to have been an attempt at settlement. ${ }^{41}$ It is evident that the Saxons who did succeed in settling in Picardy and Flanders were own brothers of the Saxons who conquered Britain." But there is surely no difficulty about

- There is no ground for saying that the landing was at Charmonth, except the unsatistactory eaggestion that 'the mouth of the river Char,' formerly Chard, in identical with 'Cerdic's shore.'

"Carmith vii. 369, ed. Kroseh, Aucth Antiquissimi, VIII. (Hon. Hist. Germ) :

Quin et Aremorious piratam Baxona [accus. oing.] tractus

Sperabet, cul pelle ealum gulcare Britennum

Ladus et assato glancum mare findere lembo.

The 'Tractas Aremoricanus' of the Notitia Dignilatum Oxcident 37 embraced more then the coust of Britanny, and included part of the Litus Baronicum of Ganl. Bidonius also records an arrival of Saxon freebooters near Sointes (Epist. viii. 6, §ु13), and, in exile at Bordean after 475, be mentions the presence of Baxons and of Herule pirstes (Ep. viii. 9j. This attack on Baintes by Kaxons, who landed at Marsas (Gironde), is mentioned in the Life of St. Bibianus or Vivianus, bishop of Baintes, in Scriptt. Rertum Merovingicarum (M. H. G.), iii. 98.

- Mullenboff, Beowubf, p. 62, has suggested that the West-Baxons crossed the English Channel from Gaul, thus explaining Cerdic and Port bearing what are essumed to be British and Homan naines.

t) Gregory of Tours, ii. 18, 19.

"Folix lahn, Urgescliciclte der yermanischen und romanischen Volker, iii. 48, thinks these Saxong were seoking 4 home, as others were doing in Britain. In 408 their iglands at the mouth of the Loire were captored by the Franks, with whom their leader afterwards numle peace. There were still Baxong on the Loire in the middle of tho girth century, for Venantius Fortunatus refers to their baete on the Loire abont 579 (Carm. iii. 4, sec. 9: ' to mihi Canobo, Cherucis adoersientibus myoparonem propetem . . . tutus . . exilasem '). This reference to them as Cherois]ci is, no doubth a learned affectation, like the application of Sigambri to the Franks, Geteo to the Goths, do., and does not prove that they were Saxons from the south of the Elbe, still calling themselves Cherusci, as Dahn, iv. 176, holds. Zeuss, Dre Deutschen und die Nachbarstamme, p. 484 , believed 'Cherucis' to be miscopied for 'Chsocis.'

ts They have left on record loosl names of a peculiarly English complexion, such as Diorwaldingatur. See upon these names Waits, Las alte Hocht der salisechen Branken, Kiel, 1846, p. 58 s.1.. It is noteworthy that there are traces of the settlement of 8weves in Picardy (ibid. p. 56), who are twice named as allied with the Angles of the continent in the lay of Widaith. Cl. also the Iovinasc 'A ryectol of Ptolemy, ii. 11. In the eighth century the 'Nordogquavi' (North Sueves) are called Saxons (Anrates Mettenew, Pertx, Scriptt. i. 3330; Zeass, p. B64). 
the Saxons coming all the way from the Elbe to Hampshire or Dorset. Such a voyage would lie no more difficult than to the mouth of the Loire, where the Saxons had occapied the islands before the settlement of Wessex."

There remains one more objection of Sir Henry Howorth's to deal with. This is that Hampshire cannot have been part of the original West-Saron land, because it was settled by Jutes and not by Saxons. He even claims to have found the name of these Jutes in the Meon-ware, who were, however, merely the dwellers by the river Meon, and have no more connexion with the rest of Hampshire than they have with the surname Mainwaring. All that we know about the Jutes of Hampshire is that they occupied the parts facing the Isle of Wight, and that the river Hamble was in their district. ${ }^{47}$ There is no evidence that they ever formed a separate state from Wessex, they left no trace of their language in the West-Saxon of Hampshire, and their name soon faded out of memury. ${ }^{48}$ The 'Chronicle' treats the Isle of Wight as a conquest of the West-Saxons, which was hunded over to Cerdic's 'nephews,' who are regarded as bringing reinforcements to him. It can hardly be maintained that this is improbable. Cerdic may have had grandsons or nepherws who were Jutes by race, and who may have brought a detachment of their folk to his assistance. Similar instances of co-operation are not unknown in the history of the Germanic invasions of other portions of the empire. Moreover, the Jutes were most closely connected with the Brxons. ${ }^{49}$

- See above, note 44.

"Beda, H. E. i. 15 ; iv. 14.

4 This is proved by the Chroniclc not mentioning the Jutes, except in the later addition under 449 from Beda, and by its regarling the Jutes of Wight as West Baxons. The translation of Beda ascribed to King Alfred calls the Jutes 'Geatas' (i. 12=15), which is the Euglish torm of the Cautar, whose name is preserved in Beowulf and in the Swedish province of Crotland; while Athelweard confuses them with the Danish Jutes (Old Norse Iotar, O. E. (ieotar). If Beda's form Intae, Iuti, menns that their name began with a diphthong und not with a semi-vowel, the name must represent an older Euti-, since iu only ocsurs in West-Germanic when it preceded sn $i$ (Bievers, Beitrdge, xviii. 411). The normal West-Saxon development of this would be Iate, later Fte, and this form seems to be reoorded in the dut. pl. Ylum of the Widsith leg, line 26. In Old English ethnic names were trequently declined as $i$-stems with a woak sen. pl.: e.g. Seaxe, gen. pl. Searna, so that we get a West-Baxon gen. pl. Ý toma, which ocours in the eleventh century C.C.C.C. MS. of the translation of Beds, ir. 1Q. This may postibly be represented by Itenc, Which Florenoe of Worcester records as the Engligh name of the New Forest (sub an. 1100: ' in Novs Foresta, quas lingua Anglorum Ytene nuncupatur'). The form Eota-land of the other MBS. of the tranele. tion of Beds, iv. 16, is Anglian, and suguests a nom. pl. Eotas, corresponding to a West-Baxon Ietas, Ytas, and to the Northumbrian Iittas that seems to be recorded in Beda's latinised Intae, Iuti. As this translation calls them Geatas in book i., it is probable that the E'ota of book iv. is merely a modernisation of Beds's form, and not a form with which the translator was fanniliar.

- They are joined with the Baxons in the letter of King Theodebert to Justinien, 684-547 (Non. Hint. Germ., Kill). iii. 13y). in which he informs the emperor of the provinces in which he dwells and of the people who have submitted to him. Attor 
Sir Henry Howorth, having thus eliminated Hampshire from the original Wessex, disposes of Dorset, Wilts, and Somerset on the ground that the word siete in the Old English forms of their names means that their inhabitants were " colonists and others planted on British ground.' It is true that the word is comected with the verb ' sit, but in compounds it is the exact equivalent of rare, and means simply 'dwellers.' Thus the Wihtvare, the folk of Wight, are called 'IFiltsaitan' in the translation of Beda's history ascribed to King Alfred. ${ }^{\text {s0 }}$ It is a baseless guess of Green's that scete meant ' settler' or ' colonist.' $\$ 1$

These three shires and Hampshire having been cut off from Weser, there only remain Berkshire and the counties that are recorded as later conquests. Berkshire must therefore, according to Sir Henry Howorth, be the nucleus of Wessex. He then asserts that Dorchester in Oxfordshire was the original capital of Wessex, simply because it was the see of the first bishop of the West-Saxons. mentioning the conquest of the Thuringisns, the voluntary sabmission of the Norevi, probably the Sweves who are connected with the Angles (s00 above, note 45), and the Tharingians, the Wisigoths of south Gaul, he procesds: 'Pannoniam, oum Baronibus Euciis [for Eutiis?], qui so nobis voluntete propris tradiderant; por Danubium et limitem Pannonise asque in ocenni littoribus, custodiente Deo, dominstio nostra porrigetw.' The mention of Pannonis presents = difficulty. Zeuss, Dic Deutselven. p. 367, proposed to emend it to Aquitaniam, but Britanniam, which is omitted, may be intended. These Eutian Saxons, or Saxons and Eutii, might in that case be the inhebitants of the Baxon eettlements in Picardy, or the Baxons of Bayeux. If they could be connected with the district of the North Suevi, who Zeuss, p. 364, thought mast be Frisians, we ahould have the curious result that, in a district where the Buevi are recorded, where there was a Frisonoleld, and in the vicinity of the Thuringiens, amongst whom some Anglii are mentioned, there was a tribe of Eutii, whose name seems to be identical with that of the conquerors of Kent, whose language was nearer to Friaian than to any other continental Germanic. It would thus theem the Eutii and Iatae were Frisians, the latter being the ppiforys who are described by Procopius as settled in Britain with the 'ArriAol. Nor must it be forgotten that at Mersebarg, in the neighbourbood of Prisonofeld, traces of a language even nearer to English than Frisian have been found; so near, in fact, that it has been ohristened ' Continental English.' The Jutes (Euthiones) are again mentioned in connexion with the Baxons by Venantius Fortanatus (Carm. ix. 1, 78, ed. Leo, Auctt. Artiqq. ir. 1, M. H. G.), writing sbout 580 :

Quem [sc. Chilpericum] Gets, Vasoo tremant, Danas, Eathio, Baxo, Britannus,

Cum patre quos aoie te domitase patet.

Terror es extremis Fresonibus htque Buebis,

Qui neque bella parnnt, sed tua frene rogant.

Omnibus his datas est timor illo indice cempo,

Et terrore novo factus ey altus amor.

Ot the races named in the first line the Danes and the Euthiones are the only two who are not recorded as dwelling in Gaul at this time, and it is therefore possible that they and the Saxons were eettlers within the Frankish empire. Bat in Carm. vii. 7, 50 Venantius refers to a defest of the Saxons and Danes by Duke Lupus near the river Borden in Friesland. Ct. Ten Brink, Beowulf, p. 207.

s Lib. 1. c. $12(=15)$.

" A continental Sexon analogy may help to make this plain. The name of Holstein is a corruption of Holt-sati, and meant, as Adem of Bremen says, the 'dwellers in the wood,' in contrast to the inhabitants of the marsh recorded in Ditmarsoh. 
It preceded Winchester by less than a score of years. This is a somewhat slender basis for the conclusion that it was the capital. It might be the bishop's without being the capital. The Mercisn bishopric was at Lichfield, which has no claim to be regarded as the cepital. That title belongs to Tamworth if to any place. But why should it be assumed that the early West-Saxon kings had a capital ? Kings do not usually give away their capitals on blor, yet we read in Beda that king Cynegils of Wessex and king $O_{B}$ wald of Northumbria gave to Birinus the city called 'Dorcic' in order that he might make therein a bishop's see."s Thus Dorchester was given jointly by the two kings, and was probably purchased jointly by them. In all probsbility it was then, like most of the Roman cities, a 'waste chester,' a memorial of the devastating march of the English conquerors. This is supported by the fact that the ' Chronicle ' records under 571-Sir Henry Howorth's condemnation of this work does not extend beyond 560-that Cathwulf of Wesser ceptured, after a fight with the Britons, Bensington, Eynsham, Aylesbury, and Iygeanburh (at or near Luton). There is no mention of Dorchester, but this must be the date when it was conquered by the West-Barons. Bensington is four miles only from Dorchester.

This annal of 571 is fatal to Sir Henry Howorth's theory, unless he condemn it as another fabrication or unless he maintain that his imaginary landing of the West-Saxons at Dorchester took place in or immediately before that year. We have evidence that rules out of court the latter contention in the history of the settlement of Aremorica by the Britons, evidence that supports in a very remarkable way the account of the foundation of Wessex contained in the 'Chronicle' and even justifies the dates. M. Loth ${ }^{\text {s3 }}$ has recently examined the early history of this settlement, and he comes to the conclusion that the Breton and the Welsh traditions that the migration was caused by the attacks of the Saxons is correct, and that the West-Saxons had more to do with the migration than any of the other invaders of Britain. From the language of the Bretons it is plain that most of them came from the Dumnonii and Cornovii of Britain, and, indeed, the names of these tribes were applied to the kingdoms founded by them in Aremorica. As late as the twelfth century their language was, according to the competent observer Giraldus Cambrensis, intelli. gible to men of Cornwall but not to Welshmen. As M. Loth says, there is no question of Bretons in Aremorica in the fifth century; in the middle of the sixth they are masters of the greater part of

s2 Hist. Eccl. iii. 7.

w J. Loth, L'Émigration bretonice en Armorique du Ve au VII' sidcle, Paris, 1883. The results are confirmed by Arthar de la Borderie, Histoire de Bretagne: I. Les trois vies anciennes de Saint Tudual, Paris, 1887, p. 57 sqq. Roference may also be mede to Mr. Egerton Phillimore's notes in Y Cymmrador, ri. 61. 
the peninsula. ${ }^{4}$ The principal saints are said to arrive from Britain in the early part of the sixth century ; ss all the saints of that century with the exception of six are said to be immigrants from Britain or the sons of immigrants. $* 6$ An ancient genealogy of the dukes or kings of Domnonee, which goes back at least as far as the ninth century, states that Riuual, the first of them, came from Britain in the reign of Clothair, and the Chmnicum Britanni1: $\iota m$ dates the first coming of the Britons into Aremorica in the same reign (511-560)..$^{37}$ This migration attracted the notice of Procopins, who, howerer, makes the Angles and Frisians of Britain participate in it.ss It is probable that this information reached him through the embassy of Theodebert, king of Austrasia, to Byzantium between 594 and 547,: to which the Frankish king had attached some Angles to make believe that he exercised supremacy over Britain. ${ }^{60}$ Gildas, who, according to the Breton Life, was one of these immigrants, records the migration of the Britons in consequence of the Saxon invasion. ${ }^{61}$

We have thus evidence of independent origin that about the time when the West-Sarons were occupying, sccording to the 'Chronicle,' the south-west of England, the Dumnonii, the inhabitants of that district, were fleeing to Aremorica. Buch a displacement of the population might be reconciled with Sir Henry Howorth's theory by the assumption that the hypothetical arrival of the founders of Wessex at Dorchester in Oxfordshire occurred some fifty years or so before the date assigned by the 'Chronicle' ' for the arrival of Cerdic. The date can hardly be projected further backwards than this, and the period seems too short for the conquest of the district between Dorchester and Dumnonis when we consider how slow the Baxon conquest was and that we have to allow for the rolling back of the advance by the great defeat of Mons Bedonicus, which seems to have been in Dumnonia. If, as M. Loth suggests, ${ }^{62}$ they had during their raids crossed Dumnonis, their defeat must have retarded their advance for a considerable period. It is also evident that the 'Chronicle' does not mention this great defeat, and it must also omit many other battles. The account is manifestly imperfect. That is a character it must necessarily bear if it is founded upon song or tradition. It is not

II P. Uy. ss $P .159$.

พ P. 163.

27 De la Borderie, p. 58 ; Loth, p. 159.

- Bellwm Gollicum, iv. 20 ; Loth, p. 169. Zeuss, Dic Drutechen, p. 192, note *", had slready referred this passage to the emigration of the Britons.

- Loth dates it between 594 and 639, referring to Gregory of Tours, Miracula, i. 31 (read 30), which, however, gives only the king's reign.

- Procopius, l.c.

"De Excidio, c. 25.

- P. 166. It is possiblo that Clldas, c. 24, refers to Dumnonie wben he speats of the Baxons reaching the Western ocean. 
until 568 that the 'Chronicle' records any advance of the WestSaxons eastwards of their reputed landing-place. This is another feature in which it harmonises with the history recorded in the settlement of Britanny.

In place of the history told ly the 'Chronicle,' and thus supported, Sir Henry Howorth asks us to accept a purely hypothetical scheme, whose only approach to anything like evidence is the bare fact that the first West-Saxon bishopric was at Dorchester in Oxfordshire; which makes the almost universally rejected sssumption that the Litır Saronicum of Britain was inhabited by Saxons, necesserily before the end of the fourth century; ${ }^{63}$ which further assumes that the descendents of these Saxon settlers, who, we are told, had become good Roman citizenz. suddenly drop their civilisation, revert to ships, sail up the Thames, and found Wessex, without receiving any addition to their numbers, since there were no Saxon rovers on the sea at the time; and finally supposes that these Roman citizens, who must have been Christians, revert to their pagan name of Saxon and found a pagan state, whose inhabitants showed great acquaintence with the gods and demons of Germanic religion. The difficulties involved in the traditional account of the foundation of Wessex are small in comparison with those into which this imaginary history of Sir Henry Howorth would lead us.

In conclusion, I may state that I do not claim that the - Chronicle' account is to be absolutely trusted, but that it is not so hopelessly absurd as Sir Henry Howorth would have us believe, and that, whatever its defects, it is not a figment of the early tenth century. Through the mists of song and tradition we may, I think, claim that we can discern the blurred outlines of real events. As the whole of the annals in question might be written on a single sheet of paper, any attempt to vindicate them must necessarily resemble Herder's scientific work as characterised by a brilliant countryman : mehr Anvegungl'n als KeBultat", prlir Fragen als Anturuten; kiilne Hyputhesi'n, "r'ni!n Beuris."is

W. H. Stevenson.

- If the two Litora Saxonich derived their names from a Baxon population, that popalation must have been settled thereon for some time before the composition of the Notitin, for a new settlement would not at once be recorded in the official denomination.

- No part of England has preserved so muny traces of Germanic myth and aegas as Wesser, and Wilta would seem to have been a great centre of Germanic paganiam.

- Sehorer, Geschiclute der deutschen Literattir, p. 478. 